\title{
Nutrient versus consumer control of community structure in a Chesapeake Bay eelgrass habitat
}

\author{
James Grayland Douglass* ${ }^{*}$ J. Emmett Duffy, Amanda C. Spivak, \\ John Paul Richardson
}

\author{
Virginia Institute of Marine Science and College of William \& Mary School of Marine Science, PO Box 1346, \\ Gloucester Point, Virginia 23062, USA
}

\begin{abstract}
Nutrient loading can dramatically alter benthic communities and has been implicated in the worldwide decline of seagrass beds. Ongoing changes in food webs caused by overfishing could also contribute to seagrass decline. However, the interaction of these factors and the role of small invertebrate grazers in mediating them are poorly understood. We examined the relative impacts of nutrient loading and food web alteration on eelgrass Zostera marina L. community structure in Chesapeake Bay by manipulating nutrients, predatory crabs, and invertebrate grazers in field enclosures over $28 \mathrm{~d}$ in summer. Nutrient loading increased epiphyte accumulation early in the experiment, decreased eelgrass biomass, and reduced the abundance of the colonial tunicate Botryllus schlosseri. Grazers decreased epiphyte accumulation, altered the recruitment of sessile invertebrates, and sometimes damaged eelgrass via overgrazing. Crabs reduced the abundance of eelgrass, and changed the species composition and abundance of grazers and sessile invertebrates. On average, the impacts of food web alterations and nutrient loading were comparable in magnitude and tended to be additive, rather than interactive. However, the distinct responses of different taxa in the community to the experimental treatments indicated that food web structure interacted with both bottom-up and top-down forces to determine overall community organization. These results highlight the importance of incorporating food web dynamics into seagrass conservation and management efforts.
\end{abstract}

KEY WORDS: Zostera marina $\cdot$ Top-down processes $\cdot$ Bottom-up processes $\cdot$ Mesograzers $\cdot$ Nutrient loading

Resale or republication not permitted without written consent of the publisher

\section{INTRODUCTION}

A general goal of ecology is to understand how both bottom-up and top-down processes interact with food web structure to determine ecosystem responses (e.g. Hairston et al. 1960, Power 1992, Heck et al. 2000, Worm et al. 2002, Hays 2005). In ecosystems where research has focused disproportionately on either topdown or bottom-up processes, we can often greatly increase our understanding by examining the other type of process as well. For example, in the rocky intertidal, where early research focused largely on topdown processes like keystone predation (e.g. Paine 1966), recent incorporation of bottom-up processes, like changes in nutrient concentration and planktonic food supply, has helped explain the system's variability
(Menge 2000, Worm \& Lotze 2006). In seagrass ecosystems, where the early focus was on the bottom-up influence of nutrients, light, and water flow (Hemminga \& Duarte 2000), studies of top-down processes have uncovered the importance of grazing and predation (Williams \& Heck 2001, Heck \& Orth 2006, Heck et al. 2006, Valentine \& Duffy 2006, Jørgensen et al. 2007). Such research has demonstrated the potential for top-down control of seagrass growth and biomass (Hughes et al. 2004, Hays 2005, Armitage \& Fourqurean 2006). Therefore, in light of the worldwide decline of seagrass habitats (Twilley et al. 1984, Duarte 2002, Orth et al. 2006), it is important to more fully evaluate the ways in which top-down processes (and the interaction of top-down and bottom-up processes) affect seagrasses. 
A meta-analysis of 35 studies that tested grazing and/or nutrient impacts on seagrasses and associated algae found that the top-down effects of grazing were similar in magnitude to the bottom-up effects of nutrients (Hughes et al. 2004). However, few of the studies included in the meta-analysis were factorial manipulations of both grazing and nutrients that explicitly evaluated the interactive effects of these manipulations (but see Neckles et al. 1993, 1994, McGlathery 1995, Hays 2005, Heck et al. 2006). Neckles et al. (1993, 1994) found that mesograzers (small invertebrates that consume mainly epiphytes and detritus) reduced the negative effect of nutrient enrichment on seagrass biomass. Hays'(2005) results were similar; nutrient enrichment negatively affected seagrass in the absence of grazing shrimp and hermit crabs, but enhanced seagrass growth when grazers were present. In contrast, McGlathery (1995) and Heck et al. (2006) found that nutrients strengthened the negative effects of vertebrate and large invertebrate grazers on seagrass. These qualitatively different results highlight the need to better understand how grazers mediate bottom-up and top-down forces in a variety of seagrass systems.

Most studies of top-down control in seagrass have been restricted to adjacent trophic levels, such as grazer-plant interactions (Orth et al. 1984, Thayer et al. 1984, Jernakoff et al. 1996, Kirsch et al. 2002, Valentine \& Duffy 2006), or predator-prey interactions (Heck \& Orth 2006). In contrast, the influence of trophic cascades on seagrass has been suggested (Williams \& Heck 2001), but rarely tested (Heck et al. 2000, 2006, Duffy et al. 2005). This is surprising, given the recognized importance of trophic cascades in other aquatic and marine systems (Brett \& Goldman 1996, 1997, Pinnegar et al. 2000, Shurin et al. 2002, Borer et al. 2006), including freshwater benthic macrophyte habitats (e.g. Martin et al. 1992). A better understanding of trophic cascades in seagrass beds might inform better fisheries management and conservation practices (Jørgensen et al. 2007).

Though top-down control of seagrass health is proximately mediated by grazer-plant interactions, it is essential to put grazing in the context of the larger food web, because the dynamic responses of grazers to changing resource availability and predation intensity can affect the nature and strength of their impacts (Heck et al. 2000, 2006, Duffy et al. 2005). For example, while mesograzer populations generally respond to epiphyte productivity and maintain low epiphyte levels (van Montfrans et al. 1984, Edgar 1993, Neckles et al. 1994, Hughes et al. 2004, Valentine \& Duffy 2006), some mesograzer species are capable of consuming live seagrass blades and have caused destruction of seagrass, or overgrazing, in cultures (Kirkman 1978, Nienhuis \& Groenendijk 1986, Short et al. 1995, Duffy et al. 2001, 2003, Boström \& Mattila 2005). While overgrazing of seagrass in the field by vertebrates and large invertebrates is well documented (Thayer et al. 1984, McGlathery 1995, Zimmerman et al. 1996, Rose et al. 1999, Kirsch et al. 2002), it has rarely been reported for mesograzers, despite their being the dominant herbivores in many seagrass systems (Valentine \& Duffy 2006). In contrast, dramatic overgrazing by mesograzers has been observed in macroalgal systems (Kangas et al. 1982, Haahtela 1984, Salemaa 1987, Tegner \& Dayton 1987).

One factor contributing to the apparent rarity of seagrass overgrazing by mesograzers in the field may be strong top-down control by predation, which normally prevents mesograzers from reaching densities at which overgrazing can occur. Predators of mesograzers include the young of commercially and recreationally harvested fish and shellfish (Tagatz 1968, Nelson 1981, Leber 1985, Hines et al. 1990, Stoner \& Buchanan 1990, Heck et al. 2000). Therefore, overfishing could potentially reduce predation and lead to overgrazing by mesograzers. In Chesapeake Bay, juvenile blue crabs Callinectes sapidus settle in eelgrass Zostera marina L. beds, where they feed extensively on mesograzers, among other prey (Tagatz 1968, Hines et al. 1990, Stoner \& Buchanan 1990, J. E. Duffy et al. unpubl. data). Thus, over-harvesting of adult blue crabs has the potential to reduce the abundance of juvenile crabs recruiting to eelgrass beds (Lipcius \& van Engel 1990) and have cascading effects on mesograzers.

In addition to producing food and shelter for fishes and mobile invertebrates, seagrass beds also support diverse assemblages of sessile invertebrates. Some of these organisms are consumed by mobile fauna like crabs and omnivorous mesograzers, which have been shown to affect the abundance of sessile invertebrates in seagrass mesocosms (Duffy \& Harvilicz 2001, Duffy et al. 2003, 2005, France \& Duffy 2006). Consumer controls on sessile invertebrate abundance in seagrass beds merit further investigation because sessile invertebrates can strongly affect seagrasses through direct competition for space or through modification of the resource environment (Sewell 1996, Reusch \& Williams 1998).

Top-down controls in seagrass beds appear both significant and dynamic, with overgrowth by epiphytes occurring under conditions of high predation and low herbivory, and overgrazing of seagrass possible under low predation and high herbivory. Here we describe a field experiment that examined these 2 scenarios of top-down control and evaluated their relative strength and interaction with bottom-up effects of nutrient addition. Using a factorial manipulation of nutrients, mesograzers, and predators in field enclosures we tested the 
following hypotheses: (1) nutrient addition will enhance epiphyte growth and reduce seagrass growth; (2) predators will reduce the abundance of mesograzers, indirectly increasing epiphytes and decreasing seagrass growth and biomass; (3) grazer population growth will counteract increased epiphyte growth under nutrient enrichment, but this compensatory response will be inhibited in the presence of predators; (4) in the absence of predators, mesograzers will damage seagrass by overgrazing; and (5) sessile invertebrates will respond negatively to both mesograzers and predators.

\section{MATERIALS AND METHODS}

Study area. The experiment was conducted at Goodwin Islands, located at the mouth of the York River in Chesapeake Bay (Virginia, USA, $37^{\circ} 13^{\prime} \mathrm{N}, 76^{\circ} 23^{\prime} \mathrm{W}$ ). Goodwin Islands are a 315 ha archipelago of saltmarsh islands surrounded by inter-tidal flats and subtidal seagrass beds (Zostera marina and Ruppia maritima). The area has been a National Estuarine Research Reserve since 1991. It is closed to development and destructive use, but remains open to commercial and recreational fishing. Average summer and winter water temperatures are 27 and $7^{\circ} \mathrm{C}$, respectively, but temperatures can range from near $0^{\circ} \mathrm{C}$ to over $30^{\circ} \mathrm{C}$. Mean salinity is 23 to $25 \mathrm{ppt}$ during the summer and fall and 13 to 15 ppt during the winter and spring. Our experimental area was a shallow, densely vegetated cove in the SE part of the islands.

Experimental design and treatments. We designed a factorial manipulation of nutrients, crustacean mesograzers, and predatory blue crabs Callinectes sapidus, with 2 levels of each factor (presence, absence). Treatments were applied within cages. We also included uncaged plots with and without nutrient addition as controls for cage effects. Thus, there were a total of 10 unique treatments with 5 replicates each. Experimen-

Table 1. Experimental design and key to the treatment designations used in Figs. 2 to 6. Out: uncaged control plots; Con: caged control plots with no crabs or mesograzers; N: nutrient addition; $\mathrm{M}$ : caged plots where mesograzers were added; C: caged plots where blue crabs Callinectes sapidus were added. Number of undamaged replicates of each treatment at the end of the experiment indicated in parentheses

\begin{tabular}{|c|c|c|c|c|c|}
\hline & \multirow[t]{2}{*}{ Uncaged } & \multicolumn{4}{|c|}{ - Caged - } \\
\hline & & Control & Mesograzers & Crabs & Crabs/mesograzers \\
\hline No nutrients & $\begin{array}{l}\text { Out } \\
(5)\end{array}$ & $\begin{array}{l}\text { Con } \\
(4)\end{array}$ & $\begin{array}{l}M \\
\text { (5) }\end{array}$ & $\begin{array}{c}\mathrm{C} \\
(4)\end{array}$ & $\begin{array}{c}\mathrm{MC} \\
(4)\end{array}$ \\
\hline Nutrients & $\begin{array}{l}\text { OutN } \\
\text { (5) }\end{array}$ & $\begin{array}{c}\text { ConN } \\
(4)\end{array}$ & $\begin{array}{c}\mathrm{MN} \\
(4)\end{array}$ & $\begin{array}{l}\mathrm{CN} \\
(3)\end{array}$ & $\begin{array}{c}\mathrm{MCN} \\
\text { (5) }\end{array}$ \\
\hline
\end{tabular}

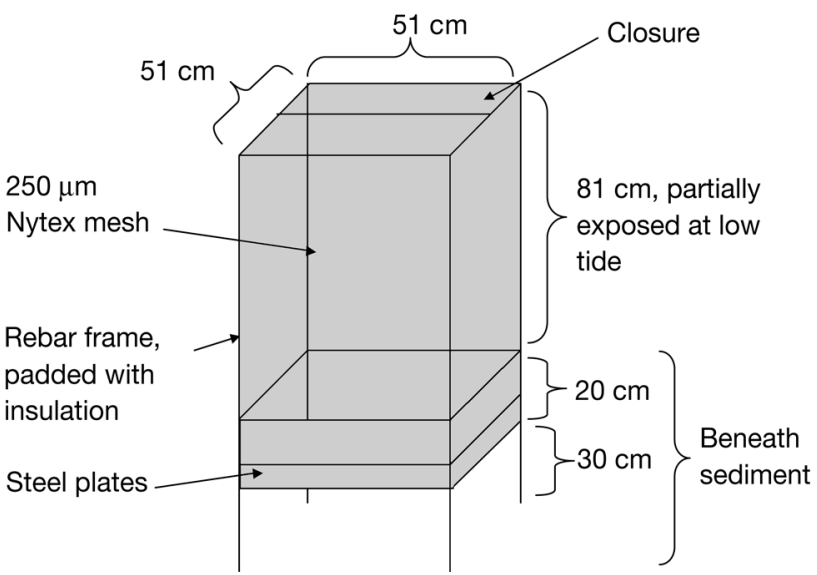

Fig. 1. Design of field enclosures used in factorial manipulation of nutrients, blue crabs, and mesograzers

tal design and shorthand for individual treatments are summarized in Table 1.

Cage design and arrangement. Cages based on designs by Per-Olav Moksnes (pers. comm.) were built around rectangular, rebar frames (Fig. 1). Frames were padded with foam pipe insulation wrapped in duct tape to minimize the risk of tearing the clear, $250 \mu \mathrm{m}$ Nytex mesh netting. This mesh size excluded predators and minimized immigration and emigration of mesograzers, while allowing light penetration and the circulation of water, fine particulates, and propagules of algae and fouling organisms. Access to the cages was through a roll-down opening in the top that was exposed at low tide. Control plots $(51 \times 51 \mathrm{~cm})$ were marked with a PVC pole at one corner and 3 small, submerged flags at the other corners. Caged and uncaged plots were haphazardly distributed and separated from one another by at least $3 \mathrm{~m}$, and treatments were randomly assigned.

Nutrient additions. Nitrate, ammonium, and phosphate were administered in the form of Osmocote ${ }^{\mathrm{TM}}$ slow-release fertilizer $(\mathrm{N}: \mathrm{P}=3: 1)$ via perforated PVC tubes that were suspended in the cages or on stakes at the uncaged control plots. We determined nutrient loading levels and diffusion distances for appropriate cage spacing based on data from a pilot experiment. Nutrient tubes were replaced weekly immediately after water samples were taken to assess nutrient treatment effectiveness. Nutrient-treated caged and uncaged plots received $200 \mathrm{~g}$ of fertilizer during the first week of the experiment. Since there was no significant difference in $\left[\mathrm{NH}_{4}^{+}\right]$between 
plots after the first week $(0.7$ and $0.5 \mu \mathrm{M}$, respectively; 1-tailed $t$-test, $\mathrm{p}=0.189$ ), we increased the fertilizer delivery to $400 \mathrm{~g}$ per plot. During the second and third weeks, the average $\left[\mathrm{NH}_{4}{ }^{+}\right]$was 4.0 and $7.6 \mu \mathrm{M}$ in treated plots and 0.7 and $2.1 \mu \mathrm{M}$ in non-treated plots, respectively.

Defaunation and faunal additions. To standardize initial density and species composition of mesograzers among plots, and to create mesograzer-free controls, all caged and uncaged plots were defaunated by treatment with Sevin $^{\mathrm{TM}}$ concentrated liquid insecticide (Carpenter 1986, Duffy \& Hay 2000). Sevin ${ }^{\mathrm{TM}}$ was applied within large, fiberglass cylinders placed around plots to prevent diffusion of the poison until all enclosed mesograzers were killed. Plots were treated with approximately $0.08 \mathrm{~g} \operatorname{Sevin}^{\mathrm{TM}} \mathrm{l}^{-1}$ seawater for 30 min, which we determined was sufficient to kill virtually all mesograzers during pilot experiments at the field site. Haphazard sampling of cages with a small dip net shortly after defaunation verified the absence of live mesograzers. Several days were allowed after defaunation for dispersal of the Sevin ${ }^{\mathrm{TM}}$ before mesograzers were added to mesograzer-addition plots. We collected mesograzers from the eelgrass bed surrounding the experimental site using a large dip net. We added 40 Gammarus mucronatus, 40 Idotea balthica, and 20 Erichsonella attenuata to each mesograzer plot, approximating their relative abundance in the dip net collections. It was not logistically feasible to stock the mesograzers at an initial density equivalent to their natural density. Thus, we considered the initial mesograzer abundance simply an inoculum and expected their populations to grow rapidly during the early part of the experiment, as in similar studies (Duffy et al. 2001, 2003, 2005). Predator-addition plots received 2 blue crabs Callinectes sapidus of carapace width 20 to $40 \mathrm{~mm}$. This density of blue crabs was well within the range observed at the field site (J. E. Duffy et al. unpubl. data).

Experimental timeline. The experiment was conducted from late May to early July 2005. On May 20, cage locations were marked with stakes. Cages were installed May 27 and defaunated on June 1. Mesograzer, crab, and nutrient treatments were applied on June 7 , which we refer to as Day 1 of the experiment. Light measurements were made on June 10, which was Day 4 of the experiment, but $14 \mathrm{~d}$ after cage placement. Blades were collected for epiphyte measurements on June 15 (Day 9) and June 29 (Day 23). Cages were destructively sampled July 5 and 6 (Days 28 and 29).

Cage maintenance and light measurements. Twice each week we checked cages and removed epiphytes from the mesh by scrubbing. Small tears in cage mesh were sewn shut when found. If a cage had a large tear or was otherwise compromised it was considered a failed replicate and not included in statistical analyses. To examine light attenuation, photosynthetically active radiation (PAR) was measured within the eelgrass canopy inside and outside of cages using a Li-Cor Spherical Light Meter (Li-Cor Biosciences). Ten cages were haphazardly selected for light measurements; 3 readings were recorded within each cage and 3 readings were recorded outside each cage, approximately $2 \mathrm{~m}$ away. This took place in late afternoon of June 10, at which point cages had been in the water and subjected to fouling for $14 \mathrm{~d}$. Cages were not scrubbed on the day of the light measurements.

Epiphyte measurements. A single eelgrass shoot (approximately 5 blades) was collected from each caged and uncaged plot on Days 9 and 23 of the experiment, June 15 and 27, respectively. Fouling material was scraped from the blades and collected on Whatman $^{\mathrm{TM}}$ GFF filters, and blade surface areas were determined with a Li-Cor 3100 area meter (Li-Cor Biosciences). We measured chlorophyll a ( $\mathrm{chl} a$ ) as a proxy for the biomass of photosynthesizing algae on the blades. Filters were extracted in $20 \mathrm{ml} 90 \%$ acetone at $-20^{\circ} \mathrm{C}$ for $24 \mathrm{~h}$. The extract was passed through $0.45 \mu \mathrm{m}$ hydrophilic PTFE membrane filters (Millipore Corporation) and absorbance was monitored at 480, 510, 630, 647, and $750 \mathrm{~nm}$ using a Shimadzu UV-1601 spectrophotometer (Shimadzu Scientific Instruments). Chl a concentration was calculated using the trichromatic equation (Lorenzen 1967), and chl a mass was calculated and normalized to blade area to serve as a proxy for epiphyte density.

Sample collection and processing. At the end of the experiment, all cages and control plots were destructively sampled. First, a $20 \times 20 \mathrm{~cm}$ grab sample of eelgrass and epifauna was taken from the center of each plot with a sampling device adapted from Virnstein \& Howard (1987). Grab samples were used because: (1) their relatively small size permits more detailed and timely processing than whole plot samples; (2) they allow for a consistent sampling technique between caged and uncaged plots; and (3) they can be directly compared with field monitoring data collected using the same apparatus (J. E. Duffy et al. unpubl. data). After a grab sample was taken, the whole plot was swept exhaustively with a dipnet, eelgrass was uprooted, and all contents of the cage were collected in a plastic bag. Both grab samples and whole plot samples were frozen at $-20^{\circ} \mathrm{C}$ until sorting. Whole-plot and grab samples were processed similarly, except that the mobile epifauna and grazing damage were not quantified in whole-plot samples.

During the sorting process, all flora and sessile epifauna were identified to the lowest taxonomic level 
possible, with the exception of microalgal epiphytes scraped from blades, which were considered en masse. Additionally, eelgrass blades were separated from roots and rhizomes. Sessile organisms were dried at $60^{\circ} \mathrm{C}$, weighed and combusted to determine ash-free dry mass (AFDM). Mobile epifauna were sorted by size class with a nested series of sieves $(8.0,5.6,4.0,2.8$, $2.0,1.4,1.0,0.71$, and $0.50 \mathrm{~mm}$ screens), then identified to species level and counted. Counts of individuals within each size class were multiplied by empirically derived coefficients to convert them to AFDM. Then the AFDM from each size class were pooled to get total AFDM for each mesograzer species within a sample (Edgar 1990).

To measure grazing damage to eelgrass blades, 10 live blades from each grab sample were randomly selected for analysis. The total length of each blade was measured in $\mathrm{cm}$ and grazing damage was recorded as the number of $\mathrm{cm}$ per blade that bore ragged scars suggestive of grazing (procedure adapted from Silliman \& Newell 2003).

Statistical analysis. A paired sample $t$-test was used to compare light levels inside and outside of cages. Mesograzer abundance, grass biomass, epiphyte density, sessile invertebrate abundance, and damage to eelgrass blades were compared among caged plots using fully factorial 3-way ANOVA with nutrients, crabs, and mesograzers as fixed factors. Uncaged plots were excluded from the ANOVA to allow a fully crossed design, so comparisons of responses between caged and uncaged plots were made separately using $t$-tests. Cages that failed during the course of the experiment $(n=7)$ were removed from the analysis. Two cages from the crabs + nutrients treatment failed. Otherwise no more than one cage from each treatment was compromised (for final $\mathrm{n}$ for each treatment, see Table 1). Data were log-transformed as necessary to achieve homogeneity of variance among treatments, as determined by Cochran's $C$-test. The proportion of variance explained by each factor and interaction was calculated as $\omega^{2}$ according to Kirk (1995). All statistical analyses were performed in Minitab version 14.1.

\section{RESULTS}

\section{Effects of caging}

After $14 \mathrm{~d}$ in the water, cages reduced light levels in the eelgrass canopy by $66 \%$. Average PAR was $262 \mu \mathrm{E}$

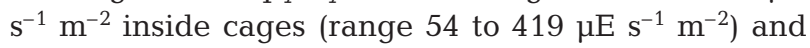
$826 \mu \mathrm{E} \mathrm{s}^{-1} \mathrm{~m}^{-2}$ outside cages (range 183 to $1332 \mu \mathrm{E} \mathrm{s}^{-1}$ $\mathrm{m}^{-2}$ ). Though light levels inside cages were reduced, they were in the range of saturating irradiance for eelgrass (Moore \& Short 2006).
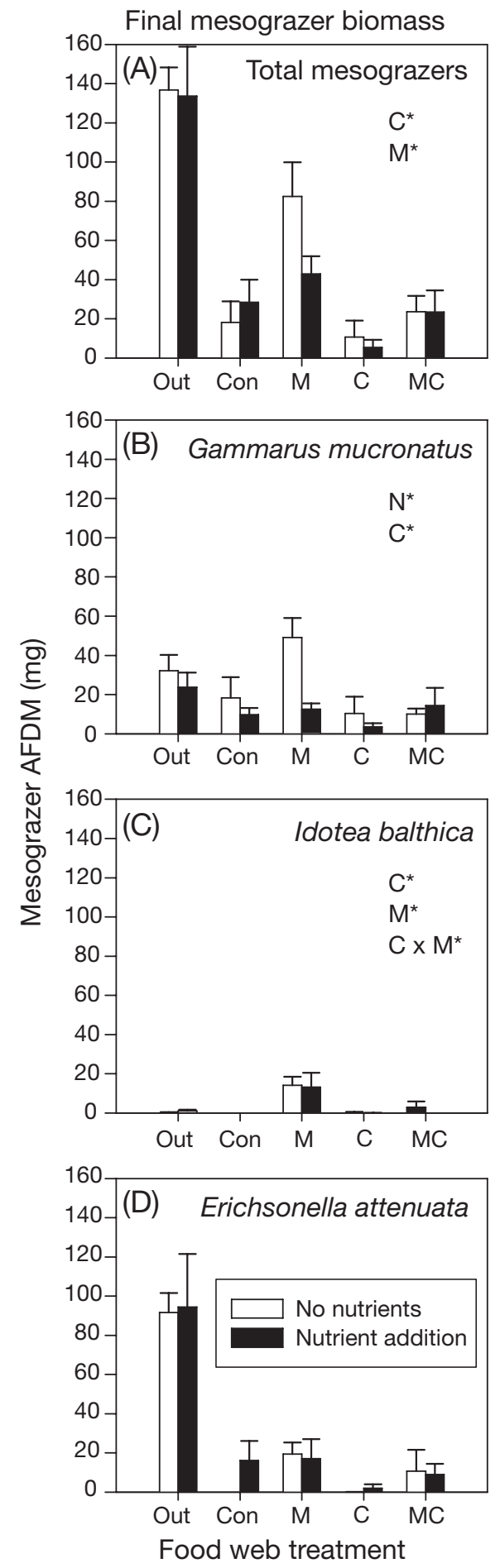

Fig. 2. Final mesograzer biomass by treatment from $400 \mathrm{~cm}^{2}$ grab samples, as calculated by the Edgar method. (A) Total mesograzer biomass, (B) Gammarus mucronatus biomass, (C) Idotea balthica biomass, and (D) Erichsonella attenuata biomass. See Table 1 for treatment code and $n$ for each treatment. Error bars are standard error of the mean (SEM). $\mathrm{N}^{*}$, $C^{*}, M^{*}$ : significant effects $(p<0.05)$ of nutrients, crabs, and mesograzers, respectively. $\mathrm{C} \times \mathrm{M}^{*}$ : significant effect of the $\mathrm{C} \times \mathrm{M}$ interaction term. AFDM: ash-free dry mass 


\section{Mesograzer abundance}

At the end of the experiment, total mesograzer biomass was higher in uncaged plots than in caged plots inoculated with mesograzers (2-tailed $t$-test, p < 0.0005). Interestingly, Erichsonella attenuata was the most abundant mesograzer outside of cages at the end of the experiment (Fig. 2D) despite being relatively rare in the dip net collections made to stock the mesograzer treatments at the beginning of the experiment (see 'Materials and methods'). Idotea balthica, on the other hand, was rare outside of cages at the end of the experiment, despite being common in the collections used for stocking. Among caged plots, total mesograzer biomass was higher in grazer-only plots than in control plots or plots with crabs (Table 2, Fig. 2A). However, there was considerable contamination of cages by the end of the experiment, as evidenced by the presence of mesograzers in caged control plots. A high proportion of these contaminant mesograzers were Gammarus mucronatus (Fig. 2B), but one replicate of the control + nutrients treatment had many E. attenuata (Fig. 2D). Crabs reduced total mesograzer biomass by $64 \%$ and reduced both G. mucronatus and Idotea balthica biomass (Table 2, Fig. 2). Nutrient effects on total mesograzer biomass were inconsistent, but nutrients decreased G. mucronatus biomass (Table 2, Fig. 2B).

\section{Epiphyte abundance}

Nutrients had strongly enhanced epiphyte growth in caged plots when epiphytic chlorophyll was first measured on Day 9 of the experiment (Table 2, Fig. 3A). At the same time, there was a non-significant trend of reduced epiphyte abundance by mesograzers ( $p=0.069)$. By Day 23 the effect of mesograzers had increased, while the nutrient effect had disappeared. Epiphytes on Day 23 were reduced by about half in both mesograzer and mesograzer + crab treatments relative to their mesograzer-free counterparts (Table 2, Fig. 3B).

\section{Eelgrass biomass}

Zostera marina biomass was lower in caged plots compared to uncaged control plots (Fig. 4). This trend was larger with the whole-plot method of sampling (Fig. 4B), probably due to the inadvertent inclusion of blades from outside the plot in uncaged samples, and reduced grass biomass at the margins of cages where cage walls penetrate the sediment. Among caged plots, both nutrients and crabs reduced eelgrass biomass (Table 2, Fig. 4). A significant interaction between nutrients and crabs for whole-plot Z. marina biomass reflects a partially redundant effect of each

Table 2. ANOVA results for variance in eelgrass community responses among caged plots. $\mathrm{df}=1$ for each main effect and interaction effect, error $\mathrm{df}=25$, and total $\mathrm{df}=32 . \omega^{2}$ is an estimate of the proportion of variance explained by an effect; $\omega^{2}=\left[\mathrm{SS}_{\text {effect }}-\right.$ $\left.\left(\mathrm{df}_{\text {effect }}\right)\left(\mathrm{MS}_{\text {error }}\right)\right] \times\left(\mathrm{MS}_{\text {error }}+\mathrm{SS}_{\text {total }}\right)^{-1}$. Bold $\omega^{2}$ values denote significant effects $(\mathrm{p}<0.05)$. AFDM: ash-free dry mass. G. mucronatus: Gammarus mucronatus; E. attenuata: Erich attenuta; I. balthica: Idotea balthica; Z. marina: Zostera marina. $\mathrm{R}^{2}$ (adj): adjusted $\mathrm{R}^{2}$. N: nutrients; C: crabs; M: mesograzers. Mean $\omega^{2}$ row gives values for each factor and interaction

\begin{tabular}{|c|c|c|c|c|c|c|c|c|c|c|c|c|c|c|c|c|}
\hline \multirow[t]{3}{*}{ Response } & \multirow{3}{*}{$\begin{array}{c}\mathrm{R}^{2} \\
\text { (adj) }\end{array}$} & \multirow{3}{*}{$\begin{array}{l}\text { MS } \\
\text { error }\end{array}$} & \multirow{2}{*}{\multicolumn{2}{|c|}{$\mathrm{N}$}} & \multirow{2}{*}{\multicolumn{2}{|c|}{$\mathrm{C}$}} & \multirow{2}{*}{\multicolumn{2}{|c|}{$M$}} & \multirow{2}{*}{\multicolumn{2}{|c|}{$\begin{array}{l}- \text { Effect } \\
\mathrm{N} \times \mathrm{C}\end{array}$}} & \multirow{2}{*}{\multicolumn{2}{|c|}{$\mathrm{N} \times \mathrm{M}$}} & \multirow{2}{*}{\multicolumn{2}{|c|}{$\mathrm{C} \times \mathrm{M}$}} & \multirow{2}{*}{\multicolumn{2}{|c|}{$\mathrm{N} \times \mathrm{C} \times \mathrm{M}$}} \\
\hline & & & & & & & & & & & & & & & & \\
\hline & & & MS & $\omega^{2}$ & MS & $\omega^{2}$ & MS & $\omega^{2}$ & MS & $\omega^{2}$ & MS & $\omega^{2}$ & MS & $\omega^{2}$ & MS & $\omega^{2}$ \\
\hline Total mesograzer AFDM & 0.448 & 565 & 608 & 0.010 & 5960 & 0.178 & 6080 & 0.192 & 289 & 0.000 & 1010 & 0.017 & 1160 & 0.021 & 1520 & 0.029 \\
\hline G. mucronatus AFDM & 0.373 & 247 & 1150 & 0.087 & 1330 & 0.095 & 992 & 0.083 & 911 & 0.059 & 142 & 0.000 & 278 & 0.006 & 779 & 0.042 \\
\hline E. attenuata AFDM & 0.056 & 202 & 98.6 & 0.000 & 489 & 0.043 & 726 & 0.076 & 96.9 & 0.000 & 249 & 0.009 & 3.60 & 0.000 & 109 & 0.000 \\
\hline I. balthica AFDM & 0.365 & 45.0 & 8.00 & 0.000 & 287 & 0.124 & 444 & 0.186 & 2.39 & 0.000 & 6.62 & 0.000 & 301 & 0.110 & 1.67 & 0.000 \\
\hline \multicolumn{17}{|l|}{ Epiphytic chl a } \\
\hline Day 9 & 0.409 & 2.51 & 63.7 & 0.411 & 0.746 & 0.000 & 9.03 & 0.040 & 1.07 & 0.000 & 4.09 & 0.011 & 0.208 & 0.000 & 0.425 & 0.000 \\
\hline Day 23 & 0.499 & 0.156 & 0.093 & 0.000 & 0.584 & 0.039 & 4.18 & 0.434 & 0.362 & 0.013 & 0.007 & 0.000 & 0.366 & 0.019 & 0.228 & 0.007 \\
\hline \multicolumn{17}{|l|}{ Z. marina AFDM } \\
\hline Grab sample & 0.409 & 0.274 & 3.76 & 0.240 & 1.79 & 0.099 & 0.679 & 0.033 & 0.328 & 0.004 & 0.501 & 0.014 & 0.713 & 0.029 & 0.000 & 0.000 \\
\hline Whole cage & 0.570 & 7.65 & 223 & 0.401 & 69.9 & 0.113 & 11.5 & 0.015 & 42.8 & 0.062 & 3.61 & 0.000 & 3.28 & 0.000 & 0.009 & 0.000 \\
\hline $\begin{array}{l}\text { Ln }(Z \text {. marina blade } \\
\left.\text { damage } \mathrm{cm}^{-1}\right)\end{array}$ & 0.364 & 0.639 & 4.55 & 0.084 & 4.38 & 0.080 & 3.07 & 0.065 & 0.924 & 0.010 & 0.118 & 0.000 & 5.58 & 0.155 & 0.010 & 0.000 \\
\hline $\begin{array}{l}\text { B. shlosseri AFDM/ } \\
\text { Z. marina }\end{array}$ & 0.250 & 0.033 & 0.340 & 0.214 & 0.040 & 0.005 & 0.014 & 0.000 & 0.080 & 0.028 & 0.017 & 0.000 & 0.020 & 0.000 & 0.075 & 0.028 \\
\hline $\begin{array}{l}\text { M. manhattensis AFDM/ } \\
\text { Z. marina }\end{array}$ & 0.328 & 0.011 & 0.006 & 0.000 & 0.134 & 0.214 & 0.041 & 0.063 & 0.006 & 0.000 & 0.011 & 0.003 & 0.041 & 0.060 & 0.011 & 0.000 \\
\hline $\begin{array}{l}\text { Bryozoan AFDM/ } \\
\text { Z. marina }\end{array}$ & 0.297 & 0.000 & 0.000 & 0.000 & 0.001 & 0.122 & 0.001 & 0.062 & 0.000 & 0.000 & 0.000 & 0.000 & 0.001 & 0.129 & 0.000 & 0.033 \\
\hline $\begin{array}{l}\text { Ln(barnacle AFDM/ } \\
\text { Z. marina) }\end{array}$ & 0.219 & 3.47 & 0.448 & 0.000 & 46.2 & 0.285 & 3.47 & 0.007 & 3.19 & 0.000 & 0.072 & 0.000 & 2.39 & 0.000 & 0.002 & 0.000 \\
\hline Mean $\omega^{2}$ & - & - & - & 0.111 & - & 0.108 & - & 0.097 & - & 0.014 & - & 0.004 & - & 0.041 & - & 0.011 \\
\hline
\end{tabular}




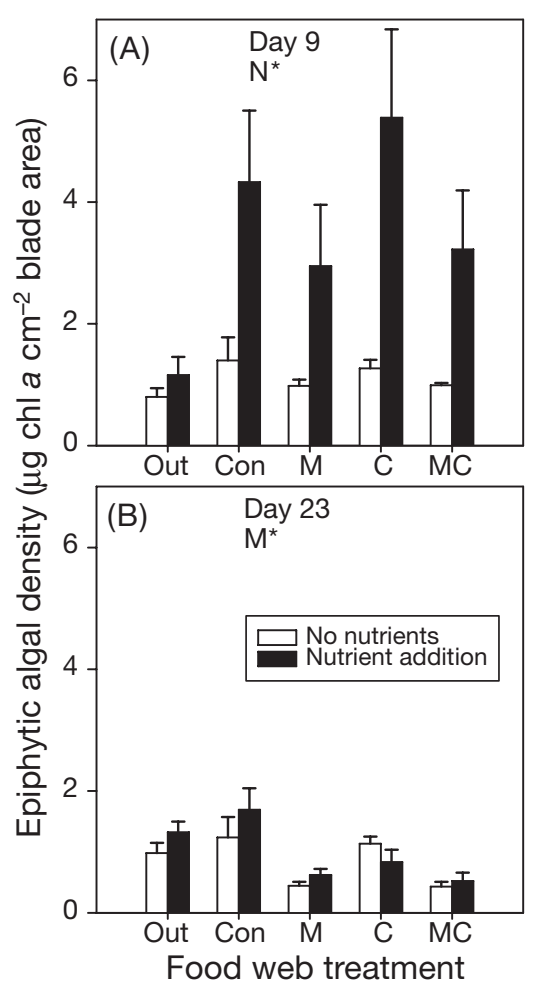

Fig. 3. Epiphytic algal density versus treatment: (A) at Day 9 of the experiment (June 15, 2005); and (B) at Day 23 of the experiment (June 29, 2005). See Table 1 for treatment code and $\mathrm{n}$ for each treatment. Error bars are SEM. $\mathrm{N}^{*}, \mathrm{M}^{*}$ : significant $(\mathrm{p}<0.05)$ effects of nutrients and mesograzers, respectively

factor in the presence of the other; when eelgrass was reduced by nutrients, it was not reduced much further by crabs, and vice versa (Table 2 ).

\section{Mesograzer and crab damage to eelgrass}

Physical damage to blades was low in caged control plots and uncaged control plots, but high in cages with either mesograzers or crabs (Table 2, Fig. 5). Damage from mesograzers vs. crabs could not be distinguished reliably, but damage in both mesograzers-only and crabs-only plots suggests that both kinds of consumers damaged eelgrass (Table 2, Fig. 5). ANOVA results reveal a significant interaction between crabs and mesograzers, suggesting that in the presence of crabs, mesograzers did not further increase blade damage (Table 2). Nutrients also increased damage, although it is difficult to tell whether the degradation of seagrass by nutrients is due to light reduction by epiphytes, or through interactions with crabs and mesograzers. Artifacts of caging may have played a role in blade damage, because little damage to blades was observed out-

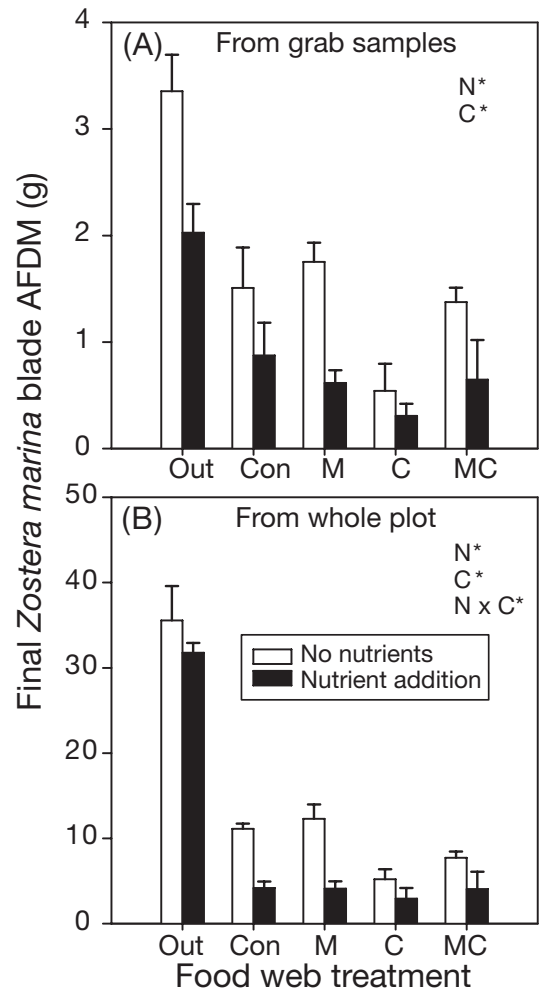

Fig. 4. Zostera marina. Above-ground biomass measured June 29-31, 2005. Ash-free dry mass (AFDW) from (A) $400 \mathrm{~cm}^{2}$ grab samples taken at the center of experimental plots, and (B) whole-plot area $\left(0.268 \mathrm{~m}^{-2}\right)$. See Table 1 for treatment code and $\mathrm{n}$ for each treatment. Error bars are SEM. $N^{*}, C^{*}, M^{*}$ : significant effects $(p<0.05)$ of nutrients, crabs, and mesograzers, respectively. $\mathrm{N} \times \mathrm{C}^{*}: \mathrm{N} \times \mathrm{C}$ interaction significant in ANOVA

side of cages, despite high mesograzer density and the presence of crabs.

\section{Sessile invertebrate recruitment}

Sessile invertebrates grew on eelgrass blades at our experimental site and were strongly affected by the experimental manipulations, particularly by crabs (Table 2, Fig. 6). The colonial tunicate Botryllus schlosseri was moderately abundant outside of the caged plots. In cages, B. schlosseri was facilitated by the presence of either mesograzers or crabs and reduced by nutrient enrichment (Table 2). A strongly contrasting pattern was observed with the solitary tunicate Molgula manhattensis, which was found only inside cages without crabs. Crabs strongly depressed bryozoan abundance, and mesograzers reduced bryozoans in the absence of crabs, as shown by a significant crab-mesograzer interaction (Table 2, Fig. 6C). Barnacles were also reduced by crabs (Table 2, Fig. 6D). 


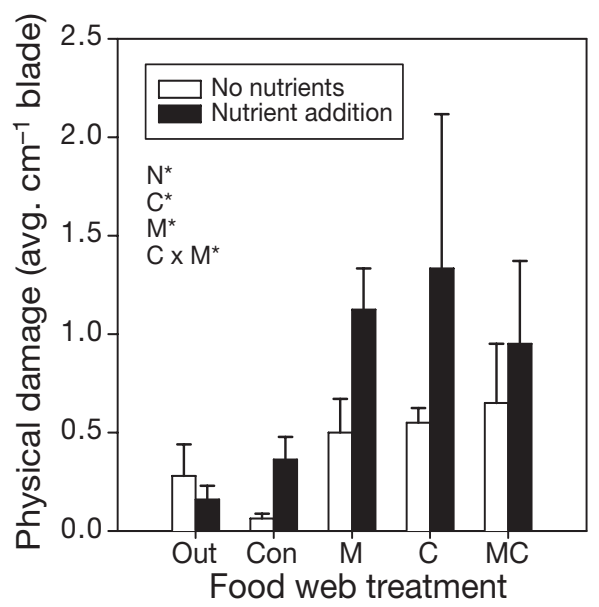

Fig. 5. Zostera marina. Physical damage to blades by treatment, measured as the average number of scarred or torn areas per linear $\mathrm{cm}$ of live blade. See Table 1 for treatment code and $\mathrm{n}$ for each treatment. Error bars are SEM. $\mathrm{N}^{*}, \mathrm{C}^{*}$, $M^{*}$ : significant effects $(p<0.05)$ of nutrients, crabs, and mesograzers, respectively. $\mathrm{C} \times \mathrm{M}^{*}: \mathrm{C} \times \mathrm{M}$ interaction significant in ANOVA

\section{Relative influence of top-down versus bottom-up effects}

ANOVAs conducted on caged plots partitioned the variance in responses of the community into components attributable to nutrients, mesograzers, crabs, and the interactions of these factors. These models explained between 6 and $57 \%$ of the variance for different community components (Table 2). The relative influence of nutrients, mesograzers, and crabs depended strongly on community components and, for epiphytic chlorophyll, the date of sampling. Of the 12 response variables analyzed, nutrients significantly influenced 6, crabs influenced 9, and mesograzers influenced 4 (Table 2). Nutrients and crabs strongly influenced final eelgrass biomass, while mesograzer effects on eelgrass biomass were minor (Table 2). However, nutrients, crabs, mesograzers, and the mesograzer-crab interaction all affected eelgrass blade damage (Table 2). Epiphytic algae were primarily influenced by nutrients at Day $9\left(\omega^{2}=0.41\right)$, but by Day 23, mesograzers were the main influence on algae $\left(\omega^{2}=0.43\right)$ and nutrient effects were negligible (Table 2). Initial mesograzer presence was the strongest influence on final mesograzer abundance, followed closely by the top-down effect of crabs; no bottom-up effect of nutrients on mesograzers was apparent (Table 2). Sessile invertebrates tended to be strongly influenced by consumers (mesograzers, crabs, and their interactions), but Botryllus schlosseri differed from the other sessile invertebrates in that it was most strongly affected by nutrients (Table 2).

\section{DISCUSSION}

Seagrass beds are often characterized by high spatial and temporal variability of seagrass biomass, epiphytic algae, epifaunal grazers, and sessile invertebrates (Marsh 1970, Nelson et al. 1982, Sewell 1996,

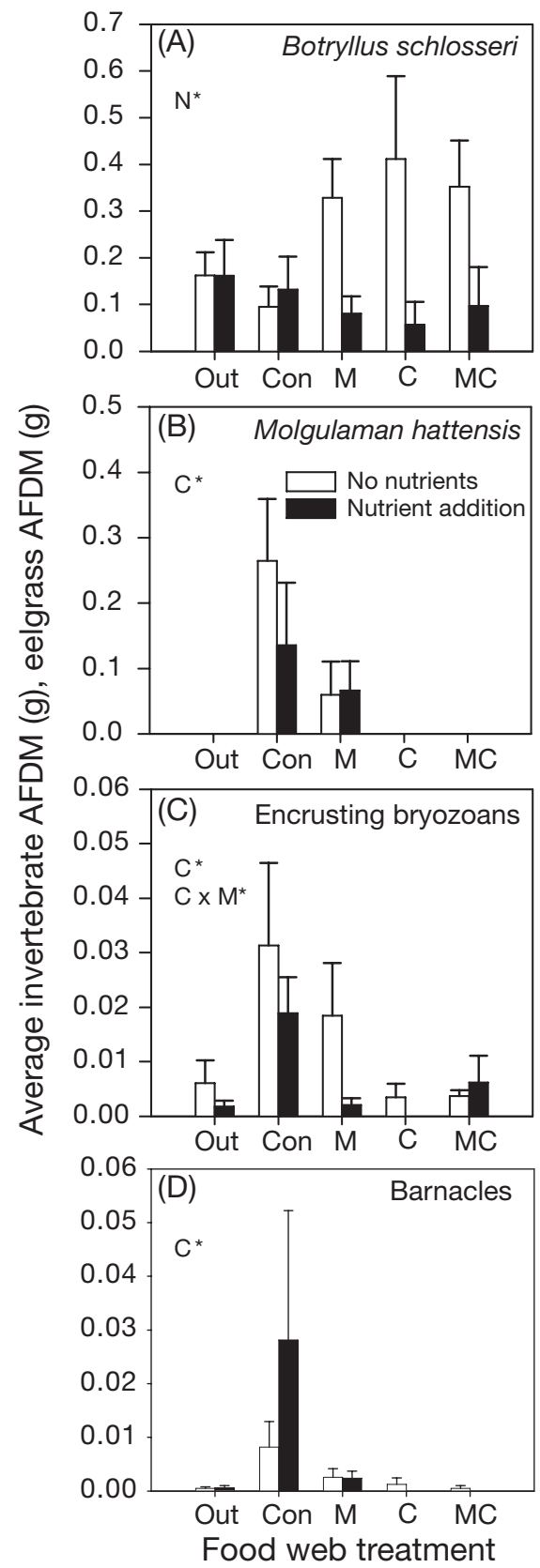

Fig. 6. Biomass of selected sessile invertebrates, normalized to Zostera marina blade biomass (ash-free dry mass, AFDM), by treatment. (A) Botryllus schlosseri; (B) Molgula manhattensis; (C) encrusting bryozoans; and (D) Balanus sp. See Table 1 for treatment code and $\mathrm{n}$ for each treatment. Error bars are SEM. $\mathrm{N}^{*}, \mathrm{C}^{*}, \mathrm{M}^{*}$ : significant effects $(\mathrm{p}<0.05)$ of nutrients, crabs, and mesograzers, respectively. $\mathrm{C} \times \mathrm{M}^{*}$ : $\mathrm{C} \times \mathrm{M}$ interaction significant in ANOVA 
Williams \& Heck 2001, Jørgensen et al. 2007). The forces generating this variability can be difficult to discern, but controlled experiments testing both topdown and bottom-up factors in seagrass beds have helped reveal these forces and how they interact (McGlathery 1995, Heck et al. 2000, 2006, Hughes et al. 2004, Hays et al. 2005). In our experiment, crustacean mesograzers, crabs, and nutrients all influenced the eelgrass community within 1 mo. Top-down impacts included the effects of blue crabs on mesograzer biomass, the impacts of crabs and mesograzers on sessile invertebrates, the reduction of epiphytes by mesograzers, and the direct damage to eelgrass blades by crabs and mesograzers. The impact of mesograzers on final eelgrass biomass was negligible, perhaps because the positive, indirect effect of their grazing on epiphytes was counteracted by the negative effect of their direct grazing on eelgrass. Another possible explanation is that other factors affecting seagrass biomass, such as nutrients, crabs, and light limitation by the cages, simply overshadowed the effects of mesograzers. Bottom-up control was evident in the stimulation of epiphyte growth by nutrients early in the experiment and in the negative effect of nutrients on eelgrass biomass by the end. Nutrient effects on total mesograzer biomass were inconsistent, perhaps because nutrients increased food availability for grazers (in the form of epiphytes and N-rich detrital material) but degraded habitat by reducing eelgrass biomass.

The scarcity of experimental field manipulations of mesograzers in the literature reflects the daunting logistical challenges involved. When designing field enclosures, there is an inevitable trade-off between maintaining light and water flow and preventing immigration/emigration of mesograzers. We were not able to completely exclude mesograzers, particularly Gammarus mucronatus, from cages in which they were not initially introduced. However, our observations confirmed that the initial defaunation was successful, and suggested that the contamination occurred progressively such that invading mesograzers were relatively scarce until later in the experiment. We attempted to maximize light and water flow by placing our cages in a shallow, high-light environment, and scrubbing them regularly to keep the mesh open. This approach was successful insofar as the caged plots were above compensating light intensity for eelgrass, 10 to $40 \mu \mathrm{E} \mathrm{s}^{-1} \mathrm{~m}^{-2}$, and were in the range of saturating irradiance, 65 to $290 \mu \mathrm{E} \mathrm{s}^{-1} \mathrm{~m}^{-2}$ (Moore \& Short 2006), at least early in the experiment. Nevertheless, eelgrass biomass was significantly lower in caged than in uncaged plots at the end of the experiment, suggesting that light limitation or other artifacts of caging did limit eelgrass growth by the end. We have considered this in our interpretation of the observed effects of nutrients, crabs, and mesograzers.

Despite the cage artifacts inherent in our study and in previous field experiments in seagrass beds (e.g. Young et al. 1976), several of our results corroborate those seen previously in mesocosm experiments in this system (Duffy \& Harvilicz 2001, Duffy et al. 2001, 2003, 2005), strengthening conclusions from both types of experiments. For example, in all experiments, mesograzers reduced epiphyte accumulation, and crabs reduced both grazer and sessile invertebrate abundance. We consider these processes in more detail below.

Crabs reduced biomass of total mesograzers, Gammarus mucronatus, and Idotea balthica (Fig. 2, Table 2). However, predation impacts on the cryptic isopod Erichsonella attenuata were weaker in our cages than in mesocosm studies. In our experiment, $E$. attenuata populations in plots with crabs were reduced by approximately $50 \%$, whereas in Duffy et al. (2005) E. attenuata were completely eliminated by crabs. The high density of grass in our field cages may have afforded $E$. attenuata more protection than the relatively sparse plantings used in that mesocosm experiment; increasing habitat complexity or vegetation density has often been associated with reduced predation (Orth et al. 1984, Heck \& Crowder 1990, Heck et al. 2006). Also, an important difference between mesocosms and field cages is the lack of infaunal prey for blue crabs, i.e. polychaetes and clams, in the former (Tagatz 1968, Stoner \& Buchanan 1990). Blue crabs may have focused foraging effort more on infaunal prey in field cages relative to mesocosms, and thus had weaker impacts on E. attenuata. Furthermore, in uncaged plots, E. attenuata abundance was higher than that of any other mesograzer, suggesting that these cryptic isopods are even less susceptible to predation in natural habitats where eelgrass tends to be even denser than in our cages. When E. attenuata abundance is normalized to grass biomass, the inside vs. outside cage difference is lessened but remains significant (2-tailed $t$-test, $\mathrm{p}=0.045$ ).

Blue crabs, and possibly mesograzers, controlled sessile invertebrates through predation, as seen previously in mesocosm and caging experiments (Seitz 1996, Duffy \& Harvilicz 2001, Duffy et al. 2003, 2005, France \& Duffy 2006). The solitary tunicate Molgula manhattensis grew to $25 \%$ of the biomass of the eelgrass itself within our caged control plots, but was rare in the presence of crabs or mesograzers, as seen previously (Duffy \& Harvilicz 2001). Thus, a disruption of the normal consumer community in an eelgrass bed might facilitate overgrowth of eelgrass by $M$. manhattensis or other sessile invertebrates, although such an effect has not been documented in the field. 
Consumers did not appear to directly affect the encrusting compound tunicate Botryllus schlosseri. However, B. schlosseri was rare in controls with no consumers and rare in nutrient-addition treatments (Fig. 6A). This pattern might be explained by competition with epiphytic algae for space during the early part of the experiment (Fig. 4A). Under low nutrients or high grazing, space may have been available for $B$. schlosseri to settle on the blades. However, with high nutrients or in the absence of effective grazing (i.e. control plots), epiphytes could have inhibited $B$. schlosseri settlement. A similar effect has been seen in mesocosm experiments where increasing grazer diversity (which corresponds with more intense epiphyte grazing) enhanced the recruitment of $B$. schlosseri (Duffy et al. 2003). B. schlosseri is often extremely abundant in Chesapeake Bay eelgrass beds (J. E. Duffy et al. unpubl. data) and may pose a threat to eelgrass health.

Reductions of epiphytes by mesograzers in our experiment were similar to those seen in mesocosm studies (Neckles et al. 1993, 1994, Hughes et al. 2004, Duffy et al. 2005), supporting the notion that mesograzers can exert important control on epiphyte abundance in the field (van Montfrans et al. 1984, Jernakoff et al. 1996). We also saw evidence for direct consumption of eelgrass by mesograzers in the form of blade damage, as seen previously in mesocosm experiments (Kirkman 1978, Short et al. 1995, Duffy \& Harvilicz 2001, Duffy et al. 2003), and occasionally observed at our study site (J. G. Douglass et al. unpubl. data). Although we did not manipulate individual mesograzer species in this experiment, the blade damage was probably caused by Idotea balthica, which is particularly destructive (Duffy et al. 2003, 2005, Boström \& Mattila 2005). However, despite the evidence for overgrazing by mesograzers, their overall contribution to blade damage was no greater than the effects of nutrients or crabs (Table 2). Crabs harmed blades through mechanical means, whereas nutrients probably weakened the eelgrass through epiphyte-mediated light reduction.

Artifacts of the caging design may have enhanced the strength of both consumer and nutrient impacts on eelgrass through several mechanisms. First, both mesograzers and predators were unnaturally confined. While densities of crabs within the cages were well within the range of observed values in the field at Goodwin Islands (J. E. Duffy et al. unpubl. data), we speculate that their confinement may have triggered more destructive behavior than would be observed at similar density in the field. Second, cages held only 1 predator species, while the predators in the field are diverse. We saw evidence of overgrazing by mesograzers in cages with no crabs, but a loss of crabs in the field would not necessarily cause overgrazing because other predators, such as fishes, could limit mesograzer populations or activity levels. Indeed, it has been suggested that the strength of top-down control depends strongly on the relative diversity of consumer and prey trophic levels (Duffy 2002, Duffy et al. 2007, J. G. Douglass et al. unpubl.). Third, cages reduced light levels. Relatively little blade damage was observed in the open eelgrass bed (Fig. 5), despite a high abundance of mesograzers and the presence of crabs outside of cages. Light reduction by the cages may have altered the eelgrass' chemical composition, making it more vulnerable to grazing. Unfortunately, we cannot verify this speculation because we did not analyze the composition of eelgrass tissues.

The relative magnitudes of consumer and nutrient effects were similar for some community responses, while for others there was a clear predominance of topdown or bottom-up control (Table 2). For example, the impact of consumers was stronger than that of nutrients for most of the sessile invertebrate species (with the exception of Botryllus schlosseri), while nutrient effects accounted for about twice as much of the variation in final eelgrass biomass as did consumer effects (Table 2). Epiphyte abundance was affected equally by nutrients and consumers, but at different times in the experiment. Early on, before populations of stocked mesograzers had had much time to increase, epiphytes bloomed in nutrient-addition treatments. Later, nutrients had little effect, with mesograzers accounting for most of the variation in epiphytes among treatments. Some of this change may have arisen from increasing light limitation caused by fouling of cages, but the topdown control by mesograzers is still clear. This result supports the hypothesis that the relative strength of top-down and bottom-up forces in natural systems can fluctuate over time (Boyer et al. 2003). Time of the year may also influence the relative sensitivity of seagrass communities to top-down and bottom-up perturbations, but this remains to be determined.

Our experiment and others demonstrate the potential for strong effects and interactions of top-down and bottom-up forces in seagrass communities (see Hughes et al. 2004 for review, also Hays 2005, Heck et al. 2006). The effects of consumers and nutrients that we observed took 2 distinct forms, both with precedent in previous experimental work. First, like Neckles et al. (1993, 1994) and Hays (2005), we observed countervailing effects of nutrients and epifaunal grazers on epiphyte accumulation. Second, like McGlathery (1995) and Heck et al. (2006), we observed negative effects of nutrients and larger consumers (blue crabs) on seagrass itself. However, whereas the negative effects that McGlathery (1995) and Heck et al. (2006) observed occurred when nutrients facilitated con- 
sumption of seagrass, the negative effects of nutrients and crabs in our study were apparently independent. The wide variation in consumer effects demonstrated by these and other experiments emphasizes the importance of studying multiple functional groups of consumers in conjunction with bottom-up factors in seagrass beds. However, small-scale experiments alone cannot determine the relative extent to which topdown and bottom-up control are realized over large scales in seagrass beds. Field survey data could be useful in achieving this end, but observational studies relating seagrass health and eutrophication have seldom included faunal abundance as a variable (Duarte 1995, Kemp et al. 2005, but see Jørgensen et al. 2007). Likewise, observations of consumer abundance and distribution in seagrass beds (e.g. Marsh 1970, Nelson et al. 1982, Edgar 1990) have rarely been related to human fisheries or potential top-down impacts on seagrass. Careful analyses of long-term monitoring data with both physical and biological components should be useful in illuminating how top-down and bottom-up processes affect seagrass beds at natural scales (Hampton \& Schindler 2006).

Acknowledgements. We thank the many individuals who contributed to this paper and the research upon which it is based. These include K. A. Moore, W. G. Reay, K. E. France, R. E. Blake, J. Bruno, N. Yavit, R. P. Burke, V. Hamilton, and K. M. Hill. The work was funded by the NSF OCE 03-52343 to J.E.D., with additional support by the NCER, STAR program, and EPA grant FP-91656901 to A.C.S.

\section{LITERATURE CITED}

Armitage AR, Fourqurean JW (2006) The short-term influence of herbivory near patch reefs varies between seagrass species. J Exp Mar Biol Ecol 339:65-74

Borer ET, Halpern BS, Seabloom EW (2006) Asymmetry in community regulation: effects of predators and productivity. Ecology 87(11):2813-2820

Boström C, Mattila J (2005) Effects of isopod grazing: an experimental comparison in temperate (Idotea balthica, Baltic Sea, Finland) and subtropical (Erichsonella attenuata, Gulf of Mexico, USA) ecosystems. Crusteaceana 78(2):185-200

Boyer AG, Swearingen RE, Blaha MA, Fortson CT, Gremillion SK, Osborn KA, Moran MD (2003) Seasonal variation in top-down and bottom-up processes in a grassland arthropod community. Oecologia 136:309-316

Brett MT, Goldman CR (1996) A meta-analysis of the freshwater trophic cascade. Proc Natl Acad Sci USA 93:7723-7726

Brett MT, Goldman CR (1997) Consumer versus resource control in freshwater pelagic food webs. Science 275:384-386

Carpenter RC (1986) Partitioning herbivory and its effects on coral reef algal communities. Ecol Monogr 56:345-363

Duarte CM (1995) Submerged aquatic vegetation in relation to different nutrient regimes. Ophelia 41:87-112

Duarte CM (2002) The future of seagrass meadows. Environ Conserv 29(2):192-106

Duffy JE (2002) Biodiversity and ecosystem function: the con- sumer connection. Oikos 99:202-219

Duffy JE, Harvilicz AM (2001) Species-specific impacts of grazing amphipods in an eelgrass bed community. Mar Ecol Prog Ser 223:201-211

Duffy JE, Hay ME (2000) Strong impacts of grazing amphipods on the organization of a benthic community. Ecol Monogr 70(2):237-263

Duffy JE, Macdonald KS, Rhode JM, Parker JD (2001) Grazer diversity, functional redundancy, and productivity in seagrass beds: an experimental test. Ecology 82(9):2317-2434

Duffy JE, Richardson JP, Canuel EA (2003) Grazer diversity effects on ecosystem functioning in seagrass beds. Ecol Lett 6:637-645

Duffy JE, Richardson JP, France KE (2005) Ecosystem consequences of diversity depend on food chain length in estuarine vegetation. Ecol Lett 8:301-309

Duffy JE, Cardinale BJ, France KE, MacIntyre PB, Thébault E, Loreau M (2007) The functional role of biodiversity in food webs: incorporating trophic complexity. Ecol Lett 10: $522-538$

Edgar GJ (1990) Population regulation, population dynamics and competition amongst mobile epifauna associated with seagrass. J Exp Mar Biol Ecol 144:205-234

Edgar GJ (1993) Measurement of the carrying capacity of benthic habitats using a metabolic-rate based index. Oecologia 95:115-121

France KE, Duffy JE (2006) Consumer diversity mediates invasion dynamics at multiple trophic levels. Oikos 113: $515-529$

Haahtela I (1984) A hypothesis of the decline of the bladder wrack (Fucus vesiculosus L.) in SW Finland in 1975-1981. Limnologica 15:345-350

Hairston NG, Smith FE, Slobodkin LB (1960) Community structure, population control, and competition. Am Nat 94(879):421-425

Hampton SE, Schindler DE (2006) Empirical evaluation of observation scale effects in community time series. Oikos 113:424-439

Hays CG (2005) Effect of nutrient availability, grazer assemblage and seagrass source population on the interaction between Thalassia testudinium (turtle grass) and its algal epiphytes. J Exp Mar Biol Ecol 314:53-68

Heck KL Jr, Crowder LB (1990) Habitat structure and predator-prey interactions. In: Bell S, McCoy E, Mushinsky H (eds) Habitat complexity: the physical arrangement of objects in space. Chapman \& Hall, New York, p 281-299

Heck KL Jr, Orth RJ (2006) Predation in seagrass meadows. In: Larkum AWD, Orth RJ, Duarte CM (eds) Seagrasses: biology, ecology and conservation. Springer, Dordrecht, p $537-550$

Heck KL Jr, Pennock JR, Valentine JF, Coen LD, Skelnar SA (2000) Effects of nutrient enrichment and small predator density on seagrass ecosystems: an experimental assessment. Limnol Oceanogr 45(5):1041-1057

Heck KL Jr, Valentine JF, Pennock JR, Chaplin G, Spitzer PM (2006) Effects of nutrient enrichment and grazing on shoalgrass Halodule wrightii and its epiphytes: results of a field experiment. Mar Ecol Prog Ser 326:145-156

Hemminga MA, Duarte CM (2000) Seagrass ecology. Cambridge University Press, New York

Hines AH, Haddon AM, Wiechert LA (1990) Guild structure and foraging impact of blue crabs and epibenthic fish in a subestuary of Chesapeake Bay. Mar Ecol Prog Ser 67: 105-126

Hughes AR, Bando KJ, Rodriguez LF, Williams SL (2004) Relative effects of grazers and nutrients on seagrasses: a meta-analysis approach. Mar Ecol Prog Ser 282:87-99 
Jernakoff P, Brearly A, Nielsen J (1996) Factors affecting grazer-epiphyte interactions in temperate seagrass meadows. Oceanogr Mar Biol Annu Rev 34:109-162

Jørgensen P, Ibarra-Obando SE, Carriquiry J (2007) Topdown and bottom-up stabilizing mechanisms in eelgrass meadows differentially affected by coastal upwelling. Mar Ecol Prog Ser 333:81-93

Kangas P, Autio H, Hällfors G, Luther H, Niemi å, Salemaa H (1982) A general model of the decline of Fucus vesiculosus at Tvärminne, south coast of Finland in 1977-81. Acta Bot Fenn 118:1-27

Kemp WM, Boynton WR, Adolf JE, Boesch DF and 14 others (2005) Eutrophication of Chesapeake Bay: historical trends and ecological interactions. Mar Ecol Prog Ser 202: $1-29$

Kirk RE (1995) Experimental design: procedures for the behavioral sciences, 3rd edn. Wadsworth, Belmont, CA

Kirkman H (1978) Growing Zostera capricorni Aschers in tanks. Aquat Bot 4:367-372

Kirsch KD, Valentine JF, Heck KL Jr (2002) Parrotfish grazing on turtlegrass Thalassia testudinium: evidence for the importance of seagrass consumption in food web dynamics of the Florida Keys National Marine Sanctuary. Mar Ecol Prog Ser 227:71-85

Leber KM (1985) The influence of predatory decapods, refuge, and microhabitat selection on seagrass communities. Ecology 66(6):1951-1964

Lipcius RN, van Engle WA (1990) Blue crab population dynamics in Chesapeake Bay: variation in abundance (York River, 1972-1988) and stock-recruit functions. Bull Mar Sci 46:180-194

Lorenzen CJ (1967) Determination of chlorophyll and phaeopigments: spectrophotometric equations. Limnol Oceanogr 12:343-346

Marsh GA (1970) A seasonal study of Zostera epibiota in the York River, VA. PhD dissertation, College of William \& Mary, Virginia Institute of Marine Science, Gloucester Point, VA

Martin TH, Crowder LB, Dumas CF, Burkholder JM (1992) Indirect effects of fish on macrophytes in Bays Mountain Lake: evidence for a littoral trophic cascade. Oecologia 89(4):476-481

McGlathery KJ (1995) Nutrient and grazing influences on a subtropical seagrass community. Mar Ecol Prog Ser 122: 239-252

Menge BA (2000) Top-down and bottom-up community regulation in marine rocky intertidal habitats. J Exp Mar Biol Ecol 250:257-289

Moore KA, Short FT (2006) Zostera: biology, ecology and management. In: Larkum AWD, Orth RJ, Duarte CM (eds) Seagrasses: biology, ecology and conservation. Springer, Dordrecht, p 361-386

Moran MD, Sheidler AR (2002) Effects of nutrients and predators on an old-field food chain: interactions of top-down and bottom-up processes. Oikos 98:116-124

Neckles HA, Wetzel RL, Orth RJ (1993) Relative effects of nutrient enrichment and grazing on epiphyte-macrophyte Zostera marina L. dynamics. Oecologia 93:275-295

Neckles HA, Koepfler ET, Haas LW, Wetzel RL, Orth RJ (1994) Relative responses by epiphytic autotrophs and heterotrophs to nutrient enrichment and grazing Zostera marina L. (eelgrass) microcosms. Estuaries 17:597-605

Nelson WG (1981) Experimental studies of decapod and fish predation on seagrass macrobenthos. Mar Ecol Prog Ser 5: 141-149

Nelson WG, Cairns KD, Virnstein RW (1982) Seasonality and spatial patterns of seagrass-associated amphipods of the
Indian River lagoon, Florida. Bull Mar Sci 32:121-129

Nienhuis PH, Groenendijk AM (1986) Consumption of eelgrass (Zostera marina) by birds and invertebrates: an annual budget. Mar Ecol Prog Ser 29:29-35

Orth RJ, Heck KL Jr, van Montfrans J (1984) Faunal communities in seagrass beds: a review of the influence of plant structure and prey characteristics in predator-prey relationships. Estuaries 7:339-350

Orth RJ, Carruthers TJB, Dennison WC, Duarte CM and 9 others (2006) A global crisis for seagrass ecosystems. BioScience 56(12):987-996

Paine RT (1966) Food web complexity and species diversity. Am Nat 100(910):65-75

Pinnegar JK, Polunin NVC, Francour P, Badalamenti F and 7 others (2000) Trophic cascades in benthic marine ecosystems: lessons for fisheries and protected-area management. Environ Conserv 27:179-200

Power ME (1992) Top-down and bottom-up forces in food webs: Do plants have primacy? Ecology 73:733-746

Reusch THB, Williams SL (1998) Variable response of native eelgrass Zostera marina to a non-indigenous bivalve Musculista senhousia. Oecologia 113:428-441

Rose CD, Sharp WC, Kenworthy WJ, Hunt JH and 6 others (1999) Overgrazing of a large seagrass bed by the sea urchin Lytechinus variegatus in outer Florida Bay. Mar Ecol Prog Ser 190:211-222

Salemaa H (1987) Herbivory and microhabitat preferences of Idotea spp. (Isopoda) in the northern Baltic Sea. Ophelia 27(1):1-15

Seitz RD (1996) The role of epibenthic predators in structuring marine soft-bottom communities along an estuarine gradient. PhD dissertation, The College of William \& Mary, Virginia Institute of Marine Science, Gloucester Point, VA

Sewell AT (1996) Eelgrass growth and abundance in an urban estuary: the negative effects of anemone coverage. MS thesis, San Diego State University, San Diego, CA

Short FT, Burdick DM, Kaldy JE (1995) Mesocosm experiments quantify the effects of eutrophication on eelgrass, Zostera marina. Limnol Oceanogr 40:740-749

Shurin JB, Borer ET, Seabloom EW, Anderson K, Blanchette CA, Broitman B, Cooper SD, Halpern BS (2002) A cross ecosystem comparison of the strength of trophic cascades. Ecol Lett 5:785-791

Silliman BR, Newell SY (2003) Fungal farming in a snail. Proc Natl Acad Sci USA 100(26):15643-15648

Stoner AW, Buchanan BA (1990) Ontogeny and overlap in the diets of four tropical Callinectes species. Bull Mar Sci 46: $3-12$

Tagatz ME (1968) Biology of the blue crab, Callinectes sapidus Rathbun, in the St. Johns River, Florida. Fish Bull 67:17-33

Tegner MJ, Dayton PK (1987) El Niño effects on Southern California kelp forest communities. Adv Ecol Res 17: 243-279

Thayer GW, Bjorndal KA, Ogden JC, Williams SL, Zieman JC (1984) Role of larger herbivores in seagrass communities. Estuaries 7(4a):351-376

Twilley RR, Kemp WM, Staver KW, Stevenson KW, Boynton JC (1984) Nutrient enrichment of estuarine submersed vascular plant communities. I. Algal growth and effects on production of plants and associated communities. Mar Ecol Prog Ser 23:179-191

Valentine J, Duffy JE (2006) The central role of grazing in seagrass ecology. In: Larkum AWD, Orth RJ, Duarte CM (eds) Seagrasses: biology, ecology and conservation. Springer, Dordrecht, p 463-501

van Montfrans J, Wetzel RL, Orth RJ (1984) Epiphyte-grazer 
relationships in seagrass meadows: consequences for seagrass growth and production. Estuaries 7:289-309

Virnstein RW, Howard RK (1987) Motile epifauna of marine macrophytes in the Indian River Lagoon, Florida: comparisons among three species of seagrasses from adjacent beds. Bull Mar Sci 41(1):1-12

Williams DL, Heck KL Jr (2001) Seagrass community ecology. In: Bertness MD, Gaines SD, Hay ME (eds) Marine community ecology. Sinauer Associates, Sunderland, MA, p 317-338

Editorial responsibility: Otto Kinne (Editor-in-Chief), Oldendorf/Luhe, Germany
Worm B, Lotze HK (2006) Effects of eutrophication, grazing, and algal blooms on rocky shores. Limnol Oceanogr 51: 569-579

Worm B, Lotze HK, Hillebrand H, Sommer U (2002) Consumer versus resource control of species diversity and ecosystem functioning. Nature 417:848-851

Zimmerman RC, Kohrs DG, Alberte RS (1996) Top-down impact through a bottom-up mechanism: the effect of limpet grazing on growth, productivity and carbon allocation of Zostera marina L. (eelgrass). Oecologia 107:560-567

Submitted: December 19, 2006; Accepted: June 4, 2007 Proofs received from author(s): October 9, 2007 